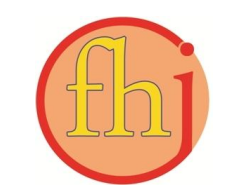

Faletehan Health Journal, 7 (1) (2020) 48-51

www. journal.Ippm-stikesfa.ac.id/ojs/index.php/FHJ

ISSN 2088-673X | e-ISSN 2597-8667

\title{
Health Education; The Comparison Between With Leaflet and Video Using Local Language In Improving Teenager's Knowledge of Adverse Health Effect of Smoking
}

\author{
Abdullah ${ }^{1}$, Andan Firmansyah², Asri Aprilia Rohman ${ }^{3}$, \\ Nurisriani Najamuddin ${ }^{4}$, Rahmayanti Puang Kuma ${ }^{5}$ \\ 1, 4, 5STIKES Bina Generasi Polewali Mandar \\ ${ }^{2}$ STIKes M uhamadiyah Ciamis \\ 3Universitas Galuh Ciamis \\ *Corresponding Author: andan.rock@gmail.com
}

\begin{abstract}
Smoking is a usual activity that we always find in our society, although most of the people know the danger of it, but the habit of smoking still can be finding in a big amount in our society, especially in the teenage area, whose stand in the biggest amount of smoker in Indonesia in this present. Health education changes attitude of young generation through knowledge, which is influence by several elements, such as delivered information, manner or props used, and language. The purpose of this research was to identify the comparison of leaflet and video using local language to improve knowledge of adverse health effect of smoking in teenager. This research used the Quasi Experiment design with Pretest and Posttest Two Group of 120 respondents. Questionnaire used to examine the knowledge of respondents. The result using Wilcoxon test showed that leaflet and video with local language are equally effective to increase knowledge of respondents of health effect of smoking $(p=-0.000)$, mean score after intervention by using the local language leaflet is 1.98 , and mean score by using local language video is 2.32 . So, local video is more effective to improve the knowledge of the teenagers about the danger of smoking than the use of local language leaflet
\end{abstract}

Keywords: Knowledge, Leaflet, Local Language, Video 
Faletehan Health Journal, 7 (1) (2020) 48-51

www. journal.Ippm-stikesfa.ac.id/ojs/index.php/FHJ

ISSN 2088-673X | 2597-8667

\section{Background}

Smokers proportion in Indonesia based on the age are 5-9 years old smoker about $1,6 \%$; 10 14 years old about $18 \%$; $15-19$ years old about $55,4 \% ; 20-24$ years old about $16,6 \% ; 25-29$ years old about $4,6 \%$; and in the age $\geq 30$ years old is about 3,8\% (Riskesdas, 2013). There are several factors that can influence teenage smoking behavior including parenting, peers, cigarette advertisements, and self-actualization, pressure or ridicule from friends (Depkes RI, 2010).

The neurologists reveal that the adolescent period is a critical step for them to experience the dependence of nicotine (Mason, Mennis, \& Schmidt, 2011). Further, Irles, Pertusa, Guijarro, and Carbonell (2013) explain that the first experience of the teenagers to smoke is happen when there are two social sub-agent who act on it, they are family and friends. It is about one third to half teenagers who had tried to smoke will be addicted in their adult period (Chalela, Velez, \& Ramirez, 2007).

Increasing adolescent knowledge about the health effects of smoking through health education is expected to reduce the number of smokers. Health education is needed to increase adolescent knowledge about self-health care. A person's knowledge will affect their lifestyle for a healthy life. Someone who has good knowledge will behave positively according to the knowledge he has. More knowledge about the health effects of smoking expectations can produce behaviors that do not stay away from cigarettes (Putri, 2010).

According to previous study, Puryanto (2012), and Kholid et al (2014) we know that there are significance influenced between before and after giving the health education to the teenagers understanding and attitude about the danger of smoking. According to Notoatmodjo (2012), health education method and technique is the way, and it can be using as the equipment or technology to deliver health education. Considering the cultural variety in Indonesia, absolutely there are some challenge factors, when languages, symbols, and signs that are communicated had experienced the long process before give the influence to the languages, symbols, and the signs that are referred (Asi and Sambas, 2015). Therefore, there are needed the media design that are suitable with society and social value, so the message can be delivered effectively to improve knowledge of teenagers about health effect of smoking.

\section{Method}

The research was quasi experiment, preposttest with two group design. Total samples were 120 teenagers aged 15-19 years old age in Kala'be Village of Aralle Distrist, Mamasa Regency. Of 120 teenagers was divided in two groups; (1) received health education intervention with local language leaflet, (2) received health education intervention with local language video. Data analysis used was Wilcoxon test, since the normality data assumption was not met.

\section{Result and discussion}

The description of respondent before and after having health education using local language leaflet. Based on table 1 above, it showed that before giving the health education by using local language leaflet the less-ability of respondents is about 32 respondents $(53,3 \%)$ then after giving the health education by using local language leaflet the less-ability of respondents was decrease to 22 respondents $(36,7 \%)$.

The respondents' description before and after having the health education by using local language video can be seen in the table 2 .

Table 1. The description of respondents knowledge before and after having health education using local language leaflet

\begin{tabular}{lcccc}
\hline \multirow{2}{*}{ Knowledge } & \multicolumn{2}{c}{ Before } & \multicolumn{2}{c}{ After } \\
\cline { 2 - 5 } & F & $\mathbf{\%}$ & F & $\mathbf{\%}$ \\
\hline Less & 32 & 53,3 & 22 & 36,7 \\
\hline Enough & 17 & 28,3 & 21 & 35,0 \\
\hline Good & 11 & 18,3 & 17 & 28,3 \\
\hline Total & $\mathbf{6 0}$ & $\mathbf{1 0 0}$ & $\mathbf{6 0}$ & $\mathbf{1 0 0}$ \\
\hline
\end{tabular}

Table 2. The description of respondents' knowledge before and after having health education using local language media

\begin{tabular}{lcccc}
\hline \multirow{2}{*}{ Knowledge } & \multicolumn{2}{c}{ Before } & \multicolumn{2}{c}{ After } \\
\cline { 2 - 5 } & F & $\mathbf{\%}$ & F & \% \\
\hline Less & 45 & 75,0 & 12 & 20,0 \\
\hline Enough & 8 & 13,3 & 11 & 18,3 \\
\hline Good & 7 & 11,7 & 37 & 61,7 \\
\hline Total & $\mathbf{6 0}$ & $\mathbf{1 0 0}$ & $\mathbf{6 0}$ & $\mathbf{1 0 0}$ \\
\hline
\end{tabular}


Based on the table 2 above, it showed that before giving the health education by using local language video, most of respondents have the less-knowledge rate about 45 respondents $(75,0$ $\%$ ) then after giving the health education by using local language video, most of the respondents have a good-knowledge about 37 respondents $(61,7 \%)$.

\section{In bivariate analysis using Wilcoxon test, the result showed as in the table 3 and 4}

Tabel 3 showed that there was difference amount between before and after giving the health education by using local language leaflet $\mathrm{p}=0.000$. The mean score before the health education was 1.65 and after giving the health education the mean sore was 1.98. Therefore, health education by using the local language leaflet affects to the knowledge about health effect of smoking among teenagers.

Tabel 4 showed that $\mathrm{t}$ there was difference amount between before and after giving the health education by using local language video $(\mathrm{p}=$ 0.000). The mean score before the health education was 1.37 and after giving the health education the mean sore was 2.32. Therefore, health education by using the local language video affects to the knowledge about health effect of smoking among teenagers.

Table 3. The difference of knowledge before and after health education using local language leaflet

\begin{tabular}{lcc}
\hline \multicolumn{1}{c}{ Leaflet Media Group } & Mean & P \\
\cline { 1 - 2 } Knowledge - Before & 1,65 & \multirow{2}{*}{0,000} \\
\hline Knowledge - After & 1,98 & \\
\hline
\end{tabular}

Table 4. The difference of knowledge before and after health education using local

\begin{tabular}{lcc}
\hline \multicolumn{1}{c}{ Media Video Group } & Mean & P \\
\cline { 1 - 2 } Knowledge - Before & 1,37 & \multirow{2}{*}{0,000} \\
\cline { 1 - 2 } Knowledge - After & 2,32 & \\
\hline
\end{tabular}

\section{Discussion}

The result of this research revealed that the use of local language leaflet and local language video affect the increasing of knowledge about the health effect of smoking in teenagers. There is the differences result of the influence of giving health education by using local language leaflet and local language video in improving knowledge of teenagers about the health effect of smoking. Local language video showed better result than local language leaflet, with quarrel mean score 0,62 . This is because video is a method that is used to make audience easy to get the information. In giving health education by using local language video, the information that is sent by voice and picture that can be accept directly by two senses, audio and visual. Video also more interest to respondent to captive the information. Therefore, health education by using video found more effective than leaflet.

According to the statement of pyramida of Edgar Dale that is describe the skill to recall the messages from the health Health education based on the technique and media. As the example is by using the sense of listening and looking, so it can make us easy to remember the messages about $50 \%$ from what we got in Health education, it's better than just remember 10\% (Bachtiar, Yusuf, M.Y., Maliya., \& Suryandari, 2015).

Previous study stated the difference of the influence of the health education by using visual with printed media to improve the motivation to stop smoking of teenagers. This research explains that giving health education by using visual audio significantly more effective to aware them to stop smoking than the printed media (Nugroho, S. A., Teguh W. Sardjojo and Ahsan, 2011).

Other findings of differences between health education using lecture and leaflet media, and health education using lecture and video found that lecture and video are the effective combination to improve knowledge of teenager regarding health effect of smoking.

\section{Conclusion}

This studu concluded that local language video is more effective to increase teenagers' knowledge about the danger of smoke rather than local language leaflet. Therefore, interesting health promotion video regarding health effect of smoking needs to be more concerned by the stakeholders as a media of health promotion to teenagers.

\section{References}

Bachtiar, Yusuf, M.Y., Maliya., \& Suryandari. (2015). Perbedaan Pengetahuan Pada 
Faletehan Health Journal, 7 (1) (2020) 48-51

www. journal.Ippm-stikesfa.ac.id/ojs/index.php/FHJ

ISSN 2088-673X | 2597-8667

Pendidikan Kesehatan Metode Ceramah Dan Media Leaflet Dengan Metode Ceramah Dan Media Video Tentang Bahaya Merokok Di SMK Kasatrian Solo. Skripsi thesis, Universitas Muhammadiyah Surakarta.

Chalela, P., Velez, L.F., \& Ramirez, A.G. (2007). Social Influences, and Attitudes and Beliefs Associated With Smoking Among Border Latino Youth. The Journal of School Health, 77(4), 187-195.

Departemen Kesehatan Indonesia. (2010). Panduan Promosi Perilaku Tidak Merokok. Kementrian Kesehatan. Jakarta.

Irles, D.L., Pertusa, M.G., Guijarro, A.B., \& Carbonell, M.J.F. (2013). Parent and peer influence models in the onset of adolescent smoking. Health and Addictions, 13 (10), 5966.

Kholid Fahdi, Faisal, dkk. (2014). Pengaruh Pendidikan Kesehatan Terhadap Pengetahuan, Sikap Dan Tindakan Merokok Pada Remaja Di Desa Jati Kabupaten Garut. Universitas Padjadjaran Bandung.
Mason, M. J., Mennis, J., \& Schmidt, C. D. (2011). A social operational model of urban adolescents' tobacco and substance use: $A$ mediational analysis. Journal of Adolescence, 34(5), 1055-1063.

Nugroho, S. A., Teguh W. Sardjojo dan Ahsan, (2011). Perbedaan Pengaruh Penyuluhan Kesehatan Antara menggunakan Media Audio Visual dengan Media Cetak terhadap Peningkatan Motivasi untuk Berhenti Merokok pada Remaja. Jurnal Keperawatan, Universitas Brawijaya Malang, Malang.

Putri. (2010). Hubungan Antara Tingkat Pengetahuan Tentang Rokok Terhadap Perilaku Merokok Pada Siswa Kelas II SMK Bhinneka Patebon Kendal. Kendal : STIKES Kendal.

Puryanto. (2012). Pengaruh Pendidikan Kesehatan Terhadap Pengetahuan dan Sikap Siswa Tentang Bahaya Rokok. Semarang : STIKES Telogorejo.

Riskesdas. (2013). Riset Kesehatan Dasar. Jakarta : Badan Penelitian dan Pengembangan Kesehatan Kementerian Kesehatan RI. 